\title{
Pathogenic Dermatophytes Survive in Nail Lesions During Oral Terbinafine Treatment for Tinea Unguium
}

\author{
Tomoyuki Iwanaga $\mathbb{B} \cdot$ Tsuyoshi Ushigami $\cdot$ Kazushi Anzawa · Takashi Mochizuki
}

Received: 6 December 2016/ Accepted: 23 January 2017/Published online: 9 March 2017

(C) The Author(s) 2017. This article is published with open access at Springerlink.com

\begin{abstract}
Tinea unguium caused by dermatophyte species are usually treated with oral antimycotic, terbinafine (TBF). To understand the mechanisms of improvement and recalcitrance of tinea unguium by oral TBF treatment, a method of quantifying dermatophyte viability in the nail was developed, and the viability of dermatophytes was analyzed in toenail lesions of 14 patients with KOH-positive tinea unguium treated with oral TBF $125 \mathrm{mg} /$ day for up to 16 weeks. Mycological tests, including $\mathrm{KOH}$ examination and fungal culture, and targeted quantitative real-time PCR for internal transcribed spacer (ITS) region, including rRNA, were demonstrated at the initial visit and after 8 and 16 weeks of treatment. Assays in eight patients showed that average ITS DNA amount significantly decreased, to $44 \%$ at 8 weeks and $36 \%$ at 16 weeks compared with $100 \%$ at initial visit. No significant difference was observed between at 8 and 16 weeks, despite the TBF concentration in the nail supposedly more than 10 -fold higher than the minimum fungicidal concentration for dermatophytes. This finding suggests the pathogenic dermatophytes in
\end{abstract}

T. Iwanaga · T. Ushigami · K. Anzawa · T. Mochizuki Department of Dermatology, Kanazawa Medical University, Uchinada, Ishikawa, Japan

T. Iwanaga $(\bowtie)$

R\&D Laboratories, POLA PHARMA INC., 560 Kashiocho, Totsuka-ku, Yokohama, Kanagawa 244-0812, Japan e-mail: t-iwanag@kanazawa-med.ac.jp;

t-iwanaga@pola-pharma.co.jp nail lesions could survive in a dormant form, such as arthroconidia, during oral TBF treatment. Both antimycotic activity and nail growth are important factors in treatment of tinea unguium.

Keywords Dermatophyte - Quantitative real-time PCR · Viability · Onychomycosis · Tinea unguium · Terbinafine $\cdot$ Trichophyton

\section{Introduction}

Onychomycosis is the most common nail disorder, with a mean prevalence of $11.4 \%$ (95\% confidence interval: 9.1-13.6\%) calculated from 21 previous reports [1]. The major pathogens of onychomycosis are dermatophyte species, a condition called tinea unguium, which produce arthroconidia from hyphae in some nail lesions [2]. Trichophyton (T.) rubrum and $T$. mentagrophytes are the most frequently isolated dermatophyte species, accounting for about $90 \%$ of patients with tinea unguium [3-5].

Most patients with tinea unguium are treated with oral antimycotics. Terbinafine (TBF) is utilized worldwide, and $82 \%$ of patients in Japan with tinea unguium treated with oral antimycotics were prescribed TBF [6]. Because the complete cure rate, defined both clinically as $100 \%$ cleaning of the toenail and mycologically as negative on $\mathrm{KOH}$ examination and fungal culture, reached $55 \%$ at week 72 for the patients treated 
with $250 \mathrm{mg} /$ day TBF for 16 weeks. This rate was significantly higher than that of patients treated with $400 \mathrm{mg} /$ day itraconazole for 1 week every 4 weeks for 16 weeks [7].

The geometric mean minimum fungicidal concentrations (MFC) of TBF have been reported to be $0.004 \mu \mathrm{g} / \mathrm{mL}$ for dermatophyte isolates $(n=39)$ [8], $0.026 \mu \mathrm{g} / \mathrm{mL}$ for $T$. rubrum isolates $(n=5)$ [9], and $0.013 \mu \mathrm{g} / \mathrm{mL}$ for T. mentagrophytes isolates $(n=18)$ [10]. Pharmacokinetically, TBF has been detected in toenails after 1 to 2 weeks, with concentrations in the distal nail at week 12 of 0.78 and $0.47 \mu \mathrm{g} / \mathrm{g}$ in patients treated with $125 \mathrm{mg} /$ day and $250 \mathrm{mg} /$ day oral TBF, respectively $[11,12]$. Because the concentration of TBF in the nail is 10 times higher than the MFC for dermatophyte species, pathogenic dermatophytes in nail lesions should be completely eradicated by oral TBF treatment. Overall, however, $45 \%$ of patients treated with TBF for 16 weeks did not reach achieve complete cure at 72 weeks [7], suggesting that fungal elements survive in nail lesions during treatment. Appropriate methods are therefore needed to evaluate the viability of fungi in nail lesions.

In a preliminary study, we developed a method, using quantitative real-time PCR, to assess dermatophyte viability in vitro [13]. In the present study, we optimized the DNA extraction method to enhance the sensitivity of this assay and evaluated dermatophyte viability in toenail lesions during oral TBF treatment. These findings may enhance understanding of the mechanisms underlying improvement and recalcitrance.

\section{Materials and Methods}

Fungal Strains

Two clinical isolates of $T$. mentagrophytes var. interdigitale (KMU 5224, KMU 6742), identified by colony morphology and PCR-RFLP analysis of internal transcribed spacer (ITS) region in the ribosomal RNA (rRNA) gene [14], were obtained from the culture collection of Kanazawa Medical University. These strains were used for standard curves and to confirm the quantification range of conidia in this study.
Primer Design

The primers, ITSF and ITSR (Table 1), were designed based on the nucleotide sequence of ITS region in the rRNA gene as previously reported [13]. The primer pair specifically detects Trichophyton species and Microsporum species; however, it does not produce any amplicon from human DNA. The amplification efficiencies using the template DNA from T. mentagrophytes var. interdigitale and T. rubrum were almost identical.

Standard Curve of Quantitative Real-Time PCR (qPCR)

Template DNA for quantitative analysis was prepared from plasmid DNA, constructed using a TOPO TA Cloning Kit (Invitrogen). The ITS region of $T$. mentagrophytes var. interdigitale (KMU 5224) was amplified using the primer pair ITS1 and ITS4 (Table 1) [15] and cloned into the plasmid vector pCR2.1-TOPO. The copy number of template for standard curves was calculated from the size of the cloned plasmid and the DNA concentration. Standard curves were generated using 10 -fold serial dilutions, yielding samples containing $10^{1}$ to $10^{7}$ copies of ITS DNA per reaction. Assays to generate standard curves were performed using a 7900HT Fast Real-Time PCR System (Applied Biosystems) and SYBR Green PCR Kit (Qiagen) in a total volume of $25 \mu \mathrm{L}$ containing $5 \mu \mathrm{L}$ of template DNA, $12.5 \mu \mathrm{L}$ of SYBR Green Master Mix, and $1 \mu \mathrm{L}$ of each primer (ITSF and ITSR, $12.5 \mu \mathrm{M})$. The amplification protocol consisted of $15 \mathrm{~min}$ of denaturation at $95{ }^{\circ} \mathrm{C}$ followed by 55 cycles of denaturation for $10 \mathrm{~s}$ at $95{ }^{\circ} \mathrm{C}$, annealing for $30 \mathrm{~s}$ at $60{ }^{\circ} \mathrm{C}$, and extension for $10 \mathrm{~s}$ at $72{ }^{\circ} \mathrm{C}$, with the addition of a dissociation stage for subsequent melting curve analysis. The amplification efficiency of the ITS primer set and the correlation coefficient $\left(\mathrm{R}^{2}\right)$ between

Table 1 Primer sequences

\begin{tabular}{ll}
\hline Primer & Sequence \\
\hline ITSF & $5^{\prime}$-AGCCCGGCTTGTGTGATG-3' \\
ITSR & $5^{\prime}$-CATTCGCCTAGGAAGCCG-3' \\
ITS1 & $5^{\prime}$-TCCGTAGGTGAACCTGCGG-3' \\
ITS4 & $5^{\prime}$-TCCTCCGCTTATTGATATGC-3' \\
\hline
\end{tabular}


copy number of template and cycle threshold $(\mathrm{Ct})$ were determined by linear approximation.

Nucleic Acid Extraction from Conidia and Quantification

A conidial suspension of T. mentagrophytes var. interdigitale (KMU 6742) was adjusted to $10^{7}$ conidia/mL with physiological saline, followed by the preparation of 10 -fold serial dilutions, yielding $10^{1}$ to $10^{7}$ conidia/mL were prepared. Aliquots of $1 \mathrm{~mL}$ of each conidial suspension transferred into $2-\mathrm{mL}$ collection tubes and centrifuged at $18,000 \times g$ for $15 \mathrm{~min}$. The supernatant was removed, and 28-32 mg of healthy human clipped nail was added to confirm the effect on fungal DNA extraction and PCR. The tubes containing the conidia were frozen in liquid nitrogen for $15 \mathrm{~min}$, and the conidia were pulverized using a Multi-Beads Shocker with a metal corn (Yasui Kikai, Osaka, Japan) at $1500 \mathrm{rpm}$ for $5 \mathrm{~s}$. DNA was extracted using the DNeasy Plant Mini Kit (Qiagen) according to the manufacturer's protocol, which included RNase A digestion and elution with $50 \mu \mathrm{L}$ AE buffer. Aliquots of $5 \mu \mathrm{L}$ were used as the templates, and qPCR was performed under the same conditions as described above. The ITS DNA copy number of each reaction was calculated from the $\mathrm{Ct}$ values and standard curve, and the relationship between ITS DNA and the number of conidia was determined using simple linear regression analysis.

Viability of Dermatophytes in Clinical Samples

This study enrolled patients with tinea unguium on the big toenail, as confirmed by positivity on $\mathrm{KOH}$ examinations, evaluated in the Division of Dermatology, Kanazawa Medical University Hospital, between November 2011 and December 2014. The main exclusion criteria included the use of antimycotic therapy during the previous 12 months, poor nail growth, and nails thicker than $3 \mathrm{~mm}$. After providing written informed consent, patients were treated with oral $125 \mathrm{mg}$ TBF once daily, the approved dose in Japan. Nail specimens were taken from the affected sites at the initial visit and 8 and 16 weeks after initiation of therapy.

Each nail specimen was subjected to $\mathrm{KOH}$ examination, fungal culture for dermatophytes with Mycosel agar slants (Becton, Dickinson and Company) and
qPCR assays. For qPCR assays, about $10 \mathrm{mg}$ nail was frozen in liquid nitrogen; DNA was extracted as described above, eluted with $50 \mu \mathrm{L}$ of AE buffer, and used with ITS primer pair ITSF and ITSR in qPCR assays as described above. Copy number per $1 \mathrm{mg}$ nail sample was calculated using standard curves. If sufficient nail specimens could not be obtained for these three tests, qPCR tests were given priority. Significant differences were determined using one-way ANOVA followed by Tukey-Kramer post hoc analysis.

\section{Ethics}

The study was performed according to the guidelines of the Helsinki Declaration and was approved by the Ethics Committee of Kanazawa Medical University.

\section{Results}

Standard Curve of qPCR (Fig. 1)

A standard curve $(Y=-3.6813 \mathrm{x}+41.614$, $\left.R^{2}=0.9999\right)$ was obtained in a linear range of $10^{1}$ to $10^{7}$ copies for the $\mathrm{Ct}$ value versus the copy number of cloned ITS region of $T$. mentagrophytes var. interdigitale. The amplification efficiency was calculated as $87 \%$ from the standard curve.

Nucleic Acid Extraction from Conidia and Quantification (Fig. 2)

The quantification ranges by qPCR also ranged from $10^{1}$ to $10^{7}$ conidia when DNA samples were extracted in the presence or absence of human nail. Simple linear regression analysis showed that, under both conditions, the number of ITS DNA copies correlated significantly with the number of conidia $(p<0.001$ each).

Viability of Dermatophytes in Clinical Samples (Table 2)

Fourteen patients with tinea unguium patients (six men, eight women) were enrolled in this study and were treated with $125 \mathrm{mg} /$ day oral TBF, with eight of these patients evaluated after 8 and 16 weeks. The median age of the 14 patients was 72 years (range, 59-83 years) and 13 (93\%) also had tinea pedis. 


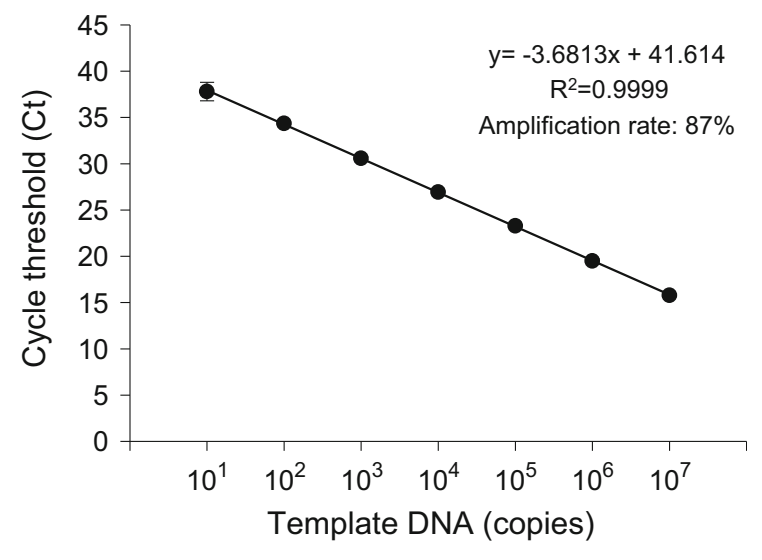

Fig. 1 Standard curve for cycle threshold versus template DNA copies by qPCR. Serial dilutions of plasmid DNA containing the cloned ITS region of T. mentagrophytes var. interdigitale were tested by qPCR using ITS primer pair ITSF and ITSR. Each point represents the mean \pm standard deviation (SD) of triplicate measurements

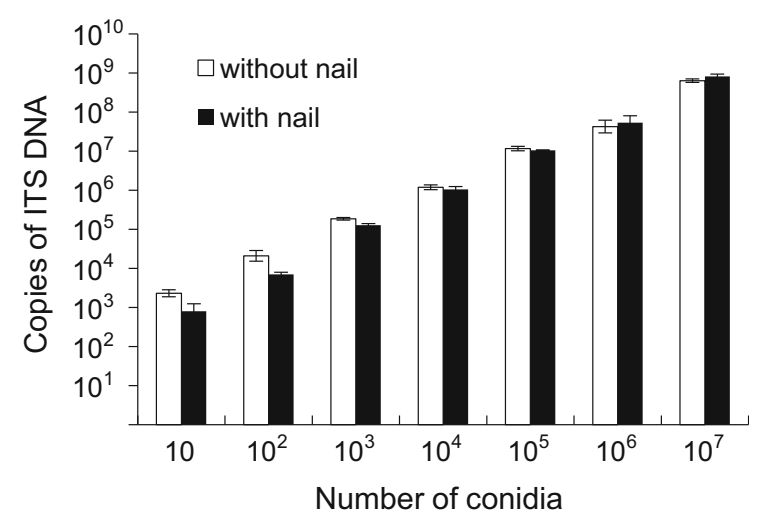

Fig. 2 Quantification range of conidia. DNA was extracted from conidia of Trichophyton mentagrophytes var. interdigitale in the presence or absence of human nail, and ITS DNA copy number was measured by qPCR. Simple linear regression analysis showed that the number of ITS DNA copies correlated significantly with the number of conidia in both the presence and absence of human nail ( $p<0.001$ each). Each bar represents the mean \pm standard deviation (SD) of the results of three experiments, with each experiment including duplicate measurements

At the start of the study (initial visit), 14 of 14 (100\%) patients were positive on $\mathrm{KOH}$ examination, 4 of $13(31 \%)$ were positive for fungal culture, and 14 of $14(100 \%)$ were positive by qPCR. After 8 weeks of treatment, none of the seven evaluated samples was positive for fungal culture, while 7 of $8(88 \%)$ were positive on $\mathrm{KOH}$ examination and 8 of $8(100 \%)$ were positive by qPCR. At 16 weeks, none of the six evaluated samples was positive for fungal culture, while 6 of 7 (86\%) were positive on $\mathrm{KOH}$ examination and 8 of $8(100 \%)$ were positive by qPCR. Although no patient attained a complete cure at week 16 , all the observed nails improved from the proximal part.

At the initial visit, dermatophyte ITS DNA copy number in the 14 nail lesions ranged from 2446 to 636,527 copies/mg. After 8 and 16 weeks of treatment, average ITS DNA amount decreased significantly, to 44 and $36 \%$ respectively, compared with $100 \%$ at initial visit $(p<0.01$ by one-way ANOVA with Tukey-Kramer multiple comparison tests). However, no significant difference was observed between at 8 and 16 weeks (Fig. 3).

\section{Discussion}

The ITS primer pair used in this study has a high amplification efficiency, with a detection limit of only 10 conidia following DNA extraction in the presence or absence of clipped nail. In comparison, a nested PCR method had an analytic sensitivity for T. rubrum and T. interdigitale of 100-1000 cells [16], indicating that our method is more sensitive than other current methods.

Although DNA is more stable than RNA, the number of ITS DNA copies decreased markedly $48 \mathrm{~h}$ after adding $1 \mu \mathrm{g} / \mathrm{mL}$ TBF to germinating conidia, with the number of copies consistent with the number of colony-forming units (CFU) [13]. These findings indicate the usefulness of ITS DNA for assessing dermatophyte viability during TBF treatment.

Our results also showed that qPCR was more sensitive than $\mathrm{KOH}$ examination and fungal culture $[17,18]$. Moreover, the wide range of ITS DNA copy number from the 14 nail lesions at the initial visit was in agreement with previous results in 32 patients with onychomycosis [19].

The average ITS DNA amount at week 16 was $36 \%$, compared with $100 \%$ at the initial visit. This finding suggests that about one-third of dermatophytes in the nail specimens survived, despite TBF in the nails possibly being at a concentration 10 -fold higher than MFC [8-11]. There are some supportive facts for understanding this result. First, MFC is highly influenced by measurement conditions. The addition of 5\% keratin to Sabouraud dextrose broth (SDB) was found to reduce the antimycotic activity of TBF against $T$. 
Table 2 Demographic and clinical characteristics of the patients included in this study

\begin{tabular}{|c|c|c|c|c|c|c|c|c|c|}
\hline No. & $\begin{array}{l}\text { Age } \\
(\mathrm{yr})\end{array}$ & Gender & Region & Tinea pedis & Therapy & Assessment & $\begin{array}{l}\text { First } \\
\text { visit }\end{array}$ & $\begin{array}{l}\text { Second } \\
\text { visit } \\
8 \text { weeks }\end{array}$ & $\begin{array}{l}\text { Third } \\
\text { visit } \\
16 \text { weeks }\end{array}$ \\
\hline 1 & 60 & $\mathrm{~F}$ & $\mathrm{R} 1$ & + & $\begin{array}{l}\text { Terbinafine } \\
125 \mathrm{mg} / \text { day }\end{array}$ & $\begin{array}{l}\text { KOH } \\
\text { Culture } \\
\text { ITS DNA } \\
\text { copy number }\end{array}$ & $\begin{array}{l}+ \\
+ \\
7811\end{array}$ & $\begin{array}{l}+ \\
\text { N. D. } \\
1788\end{array}$ & N. V. \\
\hline 2 & 65 & M & $\mathrm{L} 1$ & + & $\begin{array}{l}\text { Terbinafine } \\
125 \mathrm{mg} / \text { day }\end{array}$ & $\begin{array}{l}\text { KOH } \\
\text { Culture } \\
\text { ITS DNA } \\
\text { copy number }\end{array}$ & $\begin{array}{l}+ \\
- \\
18,486\end{array}$ & $\begin{array}{l}+ \\
- \\
9563\end{array}$ & $\begin{array}{l}+ \\
- \\
7244\end{array}$ \\
\hline 3 & 76 & $\mathrm{~F}$ & $\mathrm{R} 1$ & + & $\begin{array}{l}\text { Terbinafine } \\
125 \mathrm{mg} / \text { day } \\
\text { Luliconazole cream }\end{array}$ & $\begin{array}{l}\text { KOH } \\
\text { Culture } \\
\text { ITS DNA } \\
\text { copy number }\end{array}$ & $\begin{array}{l}+ \\
- \\
2584\end{array}$ & N. V. & N. V. \\
\hline 4 & 64 & M & $\mathrm{L} 1$ & + & $\begin{array}{l}\text { Terbinafine } \\
125 \mathrm{mg} / \text { day } \\
\text { Luliconazole cream }\end{array}$ & $\begin{array}{l}\text { KOH } \\
\text { Culture } \\
\text { ITS DNA } \\
\text { copy number }\end{array}$ & $\begin{array}{l}+ \\
- \\
9534\end{array}$ & N. V. & N. V. \\
\hline 5 & 75 & $\mathrm{~F}$ & L1 & + & $\begin{array}{l}\text { Terbinafine } \\
125 \mathrm{mg} / \text { day } \\
\text { Butenafine cream }\end{array}$ & $\begin{array}{l}\text { KOH } \\
\text { Culture } \\
\text { ITS DNA } \\
\text { copy number }\end{array}$ & $\begin{array}{l}+ \\
- \\
14,740\end{array}$ & $\begin{array}{l}+ \\
- \\
9038\end{array}$ & $\begin{array}{l}+ \\
- \\
6434\end{array}$ \\
\hline 6 & 75 & M & $\mathrm{L} 1$ & + & $\begin{array}{l}\text { Terbinafine } \\
125 \mathrm{mg} / \text { day } \\
\text { Liranaftate cream }\end{array}$ & $\begin{array}{l}\text { KOH } \\
\text { Culture } \\
\text { ITS DNA } \\
\text { copy number }\end{array}$ & $\begin{array}{l}+ \\
- \\
45,744\end{array}$ & N. V. & N. V. \\
\hline 7 & 59 & $\mathrm{~F}$ & $\mathrm{R} 1$ & + & $\begin{array}{l}\text { Terbinafine } \\
125 \mathrm{mg} / \text { day } \\
\text { Luliconazole cream }\end{array}$ & $\begin{array}{l}\text { KOH } \\
\text { Culture } \\
\text { ITS DNA } \\
\text { copy number }\end{array}$ & $\begin{array}{l}+ \\
- \\
14,373\end{array}$ & $\begin{array}{l}+ \\
- \\
8119\end{array}$ & $\begin{array}{l}+ \\
\text { N. D. } \\
1851\end{array}$ \\
\hline 8 & 66 & M & $\mathrm{L} 1$ & + & $\begin{array}{l}\text { Terbinafine } \\
125 \mathrm{mg} / \text { day } \\
\text { Lanoconazole } \\
\text { cream }\end{array}$ & $\begin{array}{l}\text { KOH } \\
\text { Culture } \\
\text { ITS DNA } \\
\text { copy number }\end{array}$ & $\begin{array}{l}+ \\
\text { N. D. } \\
7597\end{array}$ & N. V. & N. V. \\
\hline 9 & 71 & M & L1 & + & $\begin{array}{l}\text { Terbinafine } \\
125 \mathrm{mg} / \text { day }\end{array}$ & $\begin{array}{l}\text { KOH } \\
\text { Culture } \\
\text { ITS DNA } \\
\text { copy number }\end{array}$ & $\begin{array}{l}+ \\
- \\
47,652\end{array}$ & $\begin{array}{l}+ \\
- \\
25,928\end{array}$ & $\begin{array}{l}+ \\
- \\
38,434\end{array}$ \\
\hline 10 & 73 & $\mathrm{~F}$ & $\mathrm{R} 1$ & - & $\begin{array}{l}\text { Terbinafine } \\
125 \mathrm{mg} / \text { day }\end{array}$ & $\begin{array}{l}\text { KOH } \\
\text { Culture } \\
\text { ITS DNA } \\
\quad \text { copy number }\end{array}$ & $\begin{array}{l}+ \\
- \\
34,311\end{array}$ & $\begin{array}{l}- \\
- \\
18,173\end{array}$ & $\begin{array}{l}+ \\
- \\
21,561\end{array}$ \\
\hline 11 & 83 & $\mathrm{~F}$ & $\mathrm{R} 1$ & + & $\begin{array}{l}\text { Terbinafine } \\
125 \mathrm{mg} / \text { day }\end{array}$ & $\begin{array}{l}\text { KOH } \\
\text { Culture } \\
\text { ITS DNA } \\
\text { copy number }\end{array}$ & $\begin{array}{l}+ \\
- \\
636,527\end{array}$ & $\begin{array}{l}+ \\
- \\
155,854\end{array}$ & $\begin{array}{l}\text { N. D. } \\
\text { N. D. } \\
16,097\end{array}$ \\
\hline 12 & 73 & M & $\mathrm{L} 1$ & + & $\begin{array}{l}\text { Terbinafine } \\
125 \mathrm{mg} / \text { day }\end{array}$ & $\begin{array}{l}\text { KOH } \\
\text { Culture } \\
\text { ITS DNA } \\
\text { copy number }\end{array}$ & $\begin{array}{l}+ \\
+ \\
2446\end{array}$ & N. V. & N. V. \\
\hline 13 & 59 & $\mathrm{~F}$ & L1 & + & $\begin{array}{l}\text { Terbinafine } \\
125 \mathrm{mg} / \text { day }\end{array}$ & $\begin{array}{l}\text { KOH } \\
\text { Culture } \\
\text { ITS DNA } \\
\text { copy number }\end{array}$ & $\begin{array}{l}+ \\
+ \\
66,215\end{array}$ & $\begin{array}{l}+ \\
- \\
19,559\end{array}$ & $\begin{array}{l}+ \\
- \\
29,475\end{array}$ \\
\hline
\end{tabular}


Table 2 continued

\begin{tabular}{|c|c|c|c|c|c|c|c|c|c|c|}
\hline No. & $\begin{array}{l}\text { Age } \\
(\mathrm{yr})\end{array}$ & Gender & Region & Tinea pedis & Therapy & Assessmen & & $\begin{array}{l}\text { First } \\
\text { visit }\end{array}$ & $\begin{array}{l}\text { Second } \\
\text { visit } \\
8 \text { weeks }\end{array}$ & $\begin{array}{l}\text { Third } \\
\text { visit } \\
16 \text { weeks }\end{array}$ \\
\hline \multirow[t]{3}{*}{14} & \multirow[t]{3}{*}{74} & \multirow[t]{3}{*}{$\mathrm{F}$} & \multirow[t]{3}{*}{ L1 } & \multirow[t]{3}{*}{+} & \multirow{2}{*}{$\begin{array}{l}\text { Terbinafine } \\
125 \mathrm{mg} / \text { day }\end{array}$} & \multirow{2}{*}{\multicolumn{2}{|c|}{$\begin{array}{l}\mathrm{KOH} \\
\text { Culture }\end{array}$}} & + & \multirow[t]{3}{*}{ N. V. } & - \\
\hline & & & & & & & & + & & - \\
\hline & & & & & $\begin{array}{l}\text { Lanoconazole } \\
\text { ointment }\end{array}$ & $\begin{array}{l}\text { ITS DNA } \\
\text { copy numb }\end{array}$ & & 4819 & & 61 \\
\hline \multirow[t]{3}{*}{ Summary } & \multirow{2}{*}{$\begin{array}{l}\text { Average } \\
69.5\end{array}$} & \multirow{2}{*}{$\begin{array}{l}\text { Ratio (M:F) } \\
\quad 6: 8\end{array}$} & \multirow{2}{*}{$\begin{array}{l}\text { Ratio (L:R) } \\
\text { 9:5 }\end{array}$} & \multirow{2}{*}{$\begin{array}{l}\text { Rate of } \\
\text { complications } \\
93 \%\end{array}$} & & \multirow[t]{2}{*}{ Positive rate } & $\mathrm{KOH}$ & $100 \%$ & $88 \%$ & $86 \%$ \\
\hline & & & & & & & Culture & $31 \%$ & $0 \%$ & $0 \%$ \\
\hline & $\begin{array}{l}\text { Median } \\
72\end{array}$ & & & & & & DNA & $100 \%$ & $100 \%$ & $100 \%$ \\
\hline
\end{tabular}

N.D. not determined; N.V. no visit

mentagrophytes to $1 / 32$ of its initial activity [20]. In addition, we confirmed that the conidia of T. mentagrophytes var. interdigitale survived more than 2 weeks in saline containing $1 \mu \mathrm{g} / \mathrm{mL} \mathrm{TBF}$, a concentration about 100 times higher than the reported MFC [10], although these conidia were completely eradicated in SDB containing $1 \mu \mathrm{g} / \mathrm{mL}$ TBF (data not shown). Further investigations under conditions similar to the actual nail environment are needed to understand actual MFC.

Second, dermatophytes form arthroconidia from hyphae in some nail lesions [2]. Dormant arthroconidia of T. mentagrophytes were found to be resistant to antimycotics, although this resistance was completely lost upon germination [21]. Moreover, the activity of TBF against conidial suspensions of Microsporum species was $1 / 2$ to $1 / 8$ than against hyphal suspensions [22]. Complete killing of T. rubrum and T. mentagrophytes in the dormant phase requires a 1000-fold higher concentration of TBF for than in the growth phase [23]. These reports suggested that the dormant forms such as arthroconidia remain alive during oral TBF treatment in nails which contain abundant keratin.

Consequently, two strategies are suggested to treat tinea unguium, application of antimycotics at a much higher concentration than MFC, and nail growth. Recently, the highly active topical antimycotics efinaconazole and luliconazole, with MFCs against dermatophytes (T. rubrum and T. mentagrophytes) ranging from 0.0156 to 1.0 and 0.002 to $0.016 \mu \mathrm{g} / \mathrm{mL}$, respectively, were introduced to treat tinea unguium $[24,25]$. Topical treatment with a $10 \%$ solution of efinaconazole for 28 days penetrated $6.0 \mathrm{mg} / \mathrm{g}$ [26]

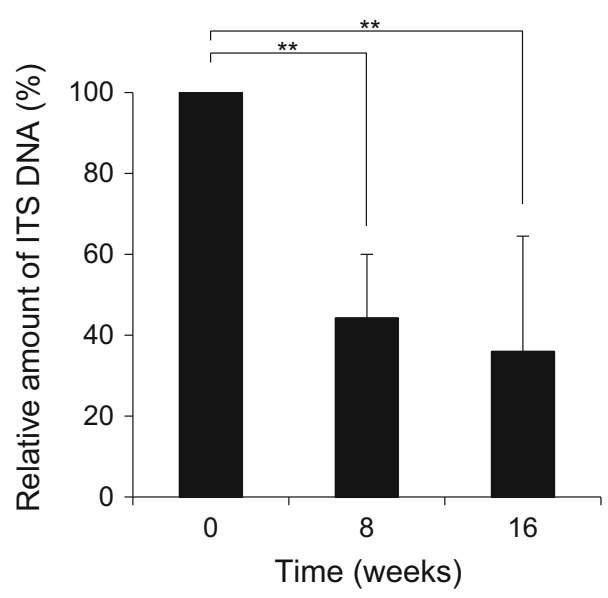

Fig. 3 The relative amount of ITS DNA before and after TBF treatment. Patients were treated with oral TBF for 16 weeks. The amount of ITS DNA in nail specimens was measured at 0,8 , and 16 weeks by qPCR and calculated relative to the initial visit $(100 \%)$. Each bar represents the mean \pm standard deviation (SD) of duplicate measurements from eight patients, with results analyzed statistically by one-way ANOVA with Tukey-Kramer multiple comparison tests. $* * p<0.01$

and could therefore deliver 6000 times higher concentration than MFC to the nail. As other strategy, nail growth promoter may be able to regrow healthy nail during which dermatophyte remains dormant by antimycotics.

In conclusion, dermatophytes in the nail survive during TBF treatment probably caused by producing dormant forms such as arthroconidia. It is suggested that both antimycotic activity and nail growth are important factors in the cure of tinea unguium. 
Open Access This article is distributed under the terms of the Creative Commons Attribution 4.0 International License (http:// creativecommons.org/licenses/by/4.0/), which permits unrestricted use, distribution, and reproduction in any medium, provided you give appropriate credit to the original author(s) and the source, provide a link to the Creative Commons license, and indicate if changes were made.

\section{References}

1. Sigurgeirsson B, Baran R. The prevalence of onychomycosis in the global population: a literature study. J Eur Acad Dermatol Venereol. 2014;28(11):1480-91. doi:10.1111/jdv.12323.

2. Yazdanparast SA, Barton RC. Arthroconidia production in Trichophyton rubrum and a new ex vivo model of onychomycosis. J Med Microbiol. 2006;55(Pt 11):1577-81. doi:10.1099/jmm.0.46474-0.

3. Havlickova B, Czaika VA, Friedrich M. Epidemiological trends in skin mycoses worldwide. Mycoses. 2008;51(Suppl 4):2-15. doi:10.1111/j.1439-0507.2008.01606.x.

4. Sei Y. 2011 Epidemiological Survey of Dermatomycoses in Japan. Med Mycol J. 2015;56(4):J129-35. doi:10.3314/ mmj.56.J129.

5. Cai W, Lu C, Li X, Zhang J, Zhan P, Xi L, et al. Epidemiology of superficial fungal infections in Guangdong, southern China: a retrospective study from 2004 to 2014 . Mycopathologia. 2016;181(5-6):387-95. doi:10.1007/ s11046-016-9986-6.

6. Iwanaga T, Anzawa K, Mochizuki T. An investigation of the clinical practice for dermatophytosis treatment using reimbursement data from health insurance societies in Japan. Jpn J Dermatol. 2015;125(12):2289-99. doi:10. 14924/dermatol.125.2289.

7. Evans EG, Sigurgeirsson B. Double blind, randomised study of continuous terbinafine compared with intermittent itraconazole in treatment of toenail onychomycosis. The LION Study Group. BMJ (Clinical research ed). 1999;318(7190):1031-5.

8. Clayton YM. Relevance of broad-spectrum and fungicidal activity of antifungals in the treatment of dermatomycoses. Br j dermatol. 1994;130(Suppl 43):7-8.

9. Osborne CS, Leitner I, Favre B, Ryder NS. Antifungal drug response in an in vitro model of dermatophyte nail infection. Med Mycol. 2004;42(2):159-63. doi:10.1080/ 13693780310001656803.

10. Hofbauer B, Leitner I, Ryder NS. In vitro susceptibility of Microsporum canis and other dermatophyte isolates from veterinary infections during therapy with terbinafine or griseofulvin. Med Mycol. 2002;40(2):179-83.

11. Matsumoto T, Tanuma H, Kaneko S, Takasu H, Nishiyama $\mathrm{S}$. Clinical and pharmacokinetic investigations of oral terbinafine in patients with tinea unguium. Mycoses. 1995;38(3-4):135-44.

12. Schatz F, Brautigam M, Dobrowolski E, Effendy I, Haberl $\mathrm{H}$, Mensing $\mathrm{H}$, et al. Nail incorporation kinetics of terbinafine in onychomycosis patients. Clin Exp Dermatol. 1995;20(5):377-83.

13. Iwanaga T, Anzawa K, Mochizuki T. Quantification of dermatophyte viability for evaluation of antifungal effect by quantitative PCR. Mycopathologia. 2014;177(5-6):241-9. doi:10.1007/s11046-014-9745-5.

14. Mochizuki T, Tanabe H, Kawasaki M, Ishizaki H, Jackson CJ. Rapid identification of Trichophyton tonsurans by PCRRFLP analysis of ribosomal DNA regions. J Dermatol Sci. 2003;32(1):25-32.

15. White T, Bruns T, Lee S, Taylor J. Amplification and direct sequencing of fungal ribosomal RNA genes for phylogenetics. In: Innis M, Gelfand D, Shinsky J, White T, editors. PCR protocols: a guide to methods and applications. London: Academic Press; 1990. p. 315-22.

16. Graser Y, Czaika V, Ohst T. Diagnostic PCR of dermatophytes - an overview. J Dtsch Dermatol Ges. 2012;10(10):721-6. doi:10.1111/j.1610-0387.2012.07964.x.

17. Luk NM, Hui M, Cheng TS, Tang LS, Ho KM. Evaluation of PCR for the diagnosis of dermatophytes in nail specimens from patients with suspected onychomycosis. Clin Exp Dermatol. 2012;37(3):230-4. doi:10.1111/j.1365-2230. 2011.04258.x.

18. Dhib I, Fathallah A, Yaacoub A, Hadj Slama F, Said MB, Zemni R. Multiplex PCR assay for the detection of common dermatophyte nail infections. Mycoses. 2014;57(1):19-26. doi:10.1111/myc.12096.

19. Miyajima Y, Satoh K, Uchida T, Yamada T, Abe M, Watanabe S, et al. Rapid real-time diagnostic PCR for Trichophyton rubrum and Trichophyton mentagrophytes in patients with tinea unguium and tinea pedis using specific fluorescent probes. J Dermatol Sci. 2013;69(3):229-35. doi:10.1016/j.jdermsci.2012.11.589.

20. Tatsumi Y, Yokoo M, Senda H, Kakehi K. Therapeutic efficacy of topically applied KP-103 against experimental tinea unguium in guinea pigs in comparison with amorolfine and terbinafine. Antimicrob Agents Chemother. 2002;46(12):3797-801. doi:10.1128/aac.46.12.3797-3801. 2002.

21. Hashimoto T, Blumenthal HJ. Survival and resistance of Trichophyton mentagrophytes arthrospores. Appl Environ Microbiol. 1978;35(2):274-7.

22. Fernandez-Torres B, Inza I, Guarro J. Comparison of in vitro antifungal susceptibilities of conidia and hyphae of dermatophytes with thick-wall macroconidia. Antimicrob Agents Chemother. 2003;47(10):3371-2. doi:10.1128/aac. 47.10.3371-3372.2003.

23. Seebacher C. Action mechanisms of modern antifungal agents and resulting problems in the management of onychomycosis. Mycoses. 2003;46(11-12):506-10.

24. Tatsumi Y, Yokoo M, Arika T, Yamaguchi H. In vitro antifungal activity of KP-103, a novel triazole derivative, and its therapeutic efficacy against experimental plantar tinea pedis and cutaneous candidiasis in guinea pigs. Antimicrob Agents Chemother. 2001;45(5):1493-9. doi:10. 1128/AAC.45.5.1493-1499.2001.

25. Maeda J, Nanjoh Y, Koga H, Toga T, Makimura K, Tsuboi R. In vitro antifungal activity of luliconazole against Trichophyton spp. Med Mycol J. 2016;57(1):J1-6. doi:10. 3314/mmj.57.J1.

26. Sakamoto M, Sugimoto N, Kawabata H, Yamakawa E, Kodera N, Pillai R, et al. Transungual delivery of efinaconazole: its deposition in the nail of onychomycosis patients and in vitro fungicidal activity in human nails. J Drugs Dermatol. 2014;13(11):1388-92. 